\title{
EARLY SPECIALIZATION IN ANCIENT EGYPTIAN MEDICINE AND ITS POSSIBLE RELATION TO AN ARCHETYPAL IMAGE OF THE HUMAN ORGANISM
}

IF THE Egyptian 'medical' papyri are judged by their language, a reasonably objective medicine must have been practised ever since the Ancient Kingdom (3200-2400 B.C.), and this is supported by the many artifacts that prove the existence at that time of lay healers, the swnw. From the whole of what is usually called the Pharaonic era, the names and titles of about 100 of these swnw are known with sufficient detail to uncover an overall picture of medical practice, due reservation being made as to their small number compared to the huge total who must have exercised their profession during these 3,000 odd years.

\section{Table 1}

The different eras of Ancient Egypt with, for each, the total number of known physicians, the total of those whose titles indicate specialization, and the number of those who claimed more than one speciality (figures collected from Jonckheere ${ }^{1}$ )

\begin{tabular}{|l|c|c|c|c|}
\hline \multicolumn{1}{|c|}{ Era } & Date, B.C. & $\begin{array}{c}\text { Total } \\
\text { number of } \\
\text { physicians }\end{array}$ & $\begin{array}{c}\text { Total } \\
\text { number of } \\
\text { specialists }\end{array}$ & $\begin{array}{c}\text { Number } \\
\text { practising } \\
\text { more than } \\
\text { one speciality }\end{array}$ \\
\hline $\begin{array}{l}\text { Ancient Kingdom } \\
\text { Middle Kingdom }\end{array}$ & $3200-2400$ & 42 & 12 & 3 \\
New Kingdom & $1590-1060$ & 29 & - & - \\
Late Epoch & until 333 & 11 & 1 & - \\
\hline
\end{tabular}

It may be significant that the oldest swnw we know, Hesy Re, who lived at the time of the legendary Imhotep (c. 2800 B.c.) was associated with the treatment of teeth, for specialization in single segments or functions of the human body seems a particular feature of the Ancient Kingdom, that vanished afterwards, except during the Late Epoch, when it timidly reappeared (Tables 1 and 2) possibly as a feature of the general archaistic tendency of that epoch.

This reappearance coincided with the visit of Herodotus who wrote: 'Medicine is practised among them on a plan of separation; each physician treats a single disorder and no more: thus the country swarms with medical practitioners some undertaking to cure diseases of the eye, others of the head, others again of the teeth, others of the intestines, and some those which are not local', 2 the last expression being better translated 'those of uncertain origin'.

According to Table 1, specialists were a minority. Did the majority, those who did not record any specialization, or just neglected to do so, belong to the class who treated diseases of 'uncertain origin'? Or should we regard Herodotus's 


\section{News, Notes and Queries}

sweeping statement with some suspicion, as we should his other affirmation that they treated a single disorder and no more, since many practitioners practised more than one speciality (Table 2)? We know that Herodotus collected his information from disparate sources, often from second- or third-hand informers, and that there are in his History many flagrant errors.

Table 2

The different recorded specializations at different epochs (from Jonckheere ${ }^{1}$ )

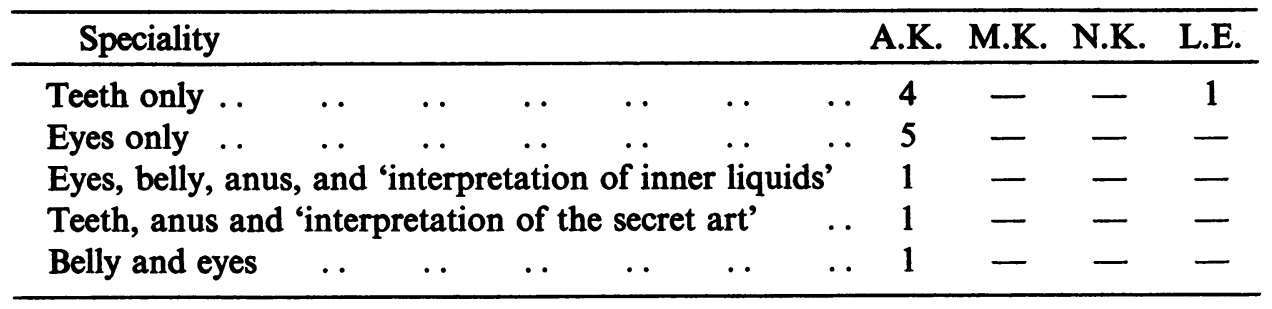

Such a narrow specialization is not on record in other parts of the ancient world. It was not a feature of Greek medicine, and we shall suggest later a possible explanation for that. Neither was it found in Mesopotamia where the activity of the various practitioners, the gallabu, the barber who practised also some minor surgery, the baru or diagnosing seer, the ashipu or exorcising therapist, the shabru who interpreted dreams, and the $a z u$ or physician, ${ }^{4}$ differed in scope but did not distinguish between the different parts of the body.

The early appearance of organ specialization in Egypt would appear natural, however, if one considered that man originally looked at each part of his body as a separate entity. In that case, medicine would have naturally started as a number of discrete specialities, that would have fused later when new physiological ideas introduced the concept of the fundamental unity of the human body.

There are some reasons to believe that this 'balkanized' body-image may be universal and innate to the human mind in spite of its apparent restriction to Egypt in medicine. Its traces are discernible in some universal traits, like the common assumption of discreet relationships between each organ and an individual god, demon, saint or star, and the general characteristics of functional or 'hysterical' manifestations.

GODS

(a) Protective. In Egypt, this is obvious in some litanies that identify separate deities with specific parts of the human body. Thus: 'The summit of thy head is Re, thy nape is Osiris, thy two ears are two King-snakes, thy arm is Horus, thy navel is the morning star, every one of thy limbs is a god'. ${ }^{5}$ The incantation against scorpion stings of the Geneva papyrus' ${ }^{6}$ begins by saying: 'You shall not have your stand on his back, Sekhmis is against [you], lady [of his back]', and then goes on repeating the same sentence for the different parts of the body, putting a different god in command of each, Sobek being lord of the perineum, Min of the buttocks, Montu of the thighs, Anukis the Nubian of the lungs, and so on. It is worthy of note 


\section{News, Notes and Queries}

that the distribution of the different parts of the body among the different gods was not yet standardized, as it was later by astrologists among the celestial bodies.

(b) Healing. If gods protected specific organs, they could also specialize in their healing. In Egypt, Meret-Seger was especially invoked to cure blindness, an affliction thought to be the punishment of those who offended her: Dwaw was the patron of oculists, and Ta-urt and Neith lorded over childbirth. In Mesopotamia, Mami, identified with Intud, protected parturition, and Gula could bring back life. ${ }^{7}$

Another possibly relevant myth is the Sumerian tale of Enki and Ninhursag that has been described as a Paradise myth announcing the Biblical Eden, but that contains elements that have no counterpart in Akkadian or Semitic mythology. In brief, the goddess Ninhursag strikes the god Enki with sickness in eight different parts of his body, in punishment of his having eaten the eight plants brought forth from his union with his great-granddaughter the goddess of plants, Uttu. Later, Ninhursag is induced, through the craft of the fox, to cure him. She does that by creating in succession eight deities, one for each part of Enki's body in which the sickness is located. (Hooke, S. H., Middle Eastern Mythology, Pelican Books, 1968, p. 33.)

Modern counterparts of these associations linger in the infinity of shrines of all denominations where a holy person is believed to heal one organ or to cure a single disease, and in the common religious practice of invoking one and the same holy personage against one disease at a certain shrine and against another elsewhere.

(c) Disease-inflicting gods and demons could also be partial to specific organs or limbs. Meret-Seger, already mentioned, was the only one in Egypt to inflict her dubious favours on specific organs. In Mesopotamia, disease-demons could be general disease-demons, but many were more selective. A well-known text says: ${ }^{8}$

\footnotetext{
The ashakku attacked man's head

The namtaru attacked man's life

The uttukku attacked man's nape

The bad alu attacked man's chest

The bad gallu attacked man's hand

The bad ikimmu attacked man's belly

The bad god attacked man's foot
}

\section{STARS}

The same basic pattern of thought must have set the stage for the development in Greece of the science of melothesia, a branch of astrology that subjected each organ and each function to the domination of a particular planet or zodiacal sign. This was mainly the work of the Stoics whose doctrines linked the 'microcosm' of the human body to the 'macrocosm' of the universe. The great appeal of melothesia is attested by its persistence in official teaching until at least the seventeenth century, and by the beautiful illustrations of 'astrological man' that illustrated Arab, European and even pre-Columbian medical treatises. These correspondences were unknown to Egypt unless we accept the litanies we have mentioned as their precursors, or to Mesopotamia that witnessed the birth of astrology, but where the use of that science was restricted to divination and to meteorological prediction. 


\section{News, Notes and Queries}

\section{FUNCTIONAL DISEASE}

It is a well-known clinical observation that 'functional' or 'hysterical' paralysis or anaesthesia affects limbs or parts of limbs in sections not conforming to nerve, root or vascular distribution. Whether these manifestations correspond to patterns developed or innate in the higher association areas of the brain (e.g. the parietal lobe), or not, they are definitely related to a semantic division of the body that seems close to archetypal body-images and to linguistic definitions of the body parts.

It remains to point out that in Greece, patients thought on similar lines when they offered ex-votos of hands, feet or other parts of the body at Epidaurus, Corinth, or, as early as pre-Greek times, in the caves of Petsofa in Crete. ${ }^{9}$ But this did not infect their lay medicine, at least in classic times, possibly because at that time the humoral theories and the philosophical concepts of the Ionian thinkers left no room for such notions. It is difficult to tell, with no available documents, what earlier views were.

We believe that this evidence points to an innate human belief in the independence of the human limbs, a belief that persisted in magic-astrologic medicine, and is still alive in some popular beliefs. In Egypt, it may have been responsible for the early subdivision of medical practitioners into specialists in diseases of specific organs. What caused the overthrow of these theories in medical teaching may have been the emergence of thinking along 'humoral' lines that were quite incompatible with the old segmentation. This happened, before Cnidos and Cos, in Egypt where peccant matter was thought to circulate in the vessels in disease and to cause either systemic or metastatic manifestations. ${ }^{10,11}$ It may have been the reason for the disappearance of specialization after the Middle Kingdom except during the archaistic revival of the Late Epochs.

\section{REFERENCES}

1 JonCKHEere, F., Les Médecins de l'Egypte Pharaonique, Brussels, Fond. Reine Elisabeth, 1958.

2 Herodotus, The History, complete translation by G. Rawlinson, New York, Tudor Publishing Company, 1956, p. 108.

3. Historiens Grecs: Hérodote, trans. by A. Barguet, Paris, Gallimard, 1964, II, 84, p. 173.

4. Contenau, G., La Médecine en Assyrie et en Babylonie, Paris, Maloine, 1938, pp. 33, 34.

5. ErmanN, A., 'Zaubersprüche für Mutter und Kind, papyrus Berlin 3027', Abh. preuss. Akad. Wiss., 1901. See also: RANKE, H., 'Die Vergottung der Glieder der menschlischen Körper', Or. Lit. Zeit, 1924, 27, 558; and HermanN, A., Deutsch. Akad. Berlin, Inst. Orient. Forsch., no. 29, Berlin, Akad. Verlag, 1955.

6. Massart, A., 'The Egyptian Geneva Papyrus MAH 15274', Mitt. Deutsch. Archaeol. Inst. Abteil. Kairo, 15, p. 172.

7. Contenau, G., op. cit., pp. 77, 93.

8. Contenau, G., op. cit., pp. 85, 86.

9. Pournaropoulos, G. C., 'Hellenic Medicine before Hippocrates', in The Origins of Medicine in Greece, Athens, Christou, 1968, p. 59.

10. Ghalioungur, P., Magic and Medical Science in Ancient Egypt, London, Hodder \& Stoughton, 1963, p. 76.

11. Steuer, R. O., and Saunders, J. B. de C., Ancient Egyptian and Cnidian Medicine, Berkeley, University of California Press, 1959.

P. GHALIOUNGUI 